\title{
犬寄地すべりの挙動に対する土質力学的検討
}

\section{Consideration on Behavior of Inuyose Landslide based on Soil Mechanics}

\author{
八木則男* 榎 明 潔* \\ Norio $\mathrm{Y}_{\mathrm{AGI}}$ \\ 矢田部龍一* \\ Ryuichi YATABE \\ Meiketsu ENoKI \\ 永 江 正 憲** \\ Masanori NAGAE
}

\begin{abstract}
The behavior of Inuyose landslide was investigated based on the soil mechanics from a standpoint of effective stress. The strength parameters in terms of effective stress on the disturbed samples were not different from ones on the undisturbed samples, that is, $c^{\prime}=0$ and $\phi^{\prime}=30^{\circ}$. The safety factor of the landslide from the stability analysis using the above strength parameters was 1.42. Therefore, creep phnomenon was considered. The relative rate of creep diformation at each stress level corresponding to each height of ground water table was calculated using the results of creep tests. The results of calculation explain qualitatively the behavior of Inuyose landslide.
\end{abstract}

\section{1. まえがき}

四国は東西に中央構造線が走り，その南側飞位置する 結晶片岩地带にいわゆる破砕带地寸べりが多く発生して いる。地すべりの安定対策工を行なう場合, 一般的には 現状の安全率を 1 として全応力解析, 西るいは, 有効応 力解析（笅密には，排水強度を用いた解析）に上り $c, \phi$ を逆算し, 対策工の効果を検討している。破砕帯地すべ りであっても,すべり面には地すべり粘土が存在してい ることが多い。粘土が存在している場合, 地すべり変形 はクリープにより生じていると思われる。また, 時間に 対する変形量も一様ではなく, 地下水位の変動化伴う有 効応力の変化の影響を受けていることが多い。したがっ て, 現状安全率を 1 と仮定して, 全応力解析に上り対策 工の効果を検討する方法には限界があると思わ机る。し かし, 地すべり地带の地形, 地質は複雑であるので, こ のような方法も現状ではしかたないとも思われるが，る し可能であれば, 有効応力の観点から土の強 度, 変形特性を考慮して解析するとより的確 に地すべり現象を解明することができるであ ろら。

本報告は，その上らな考光に基づいて，地 すべり粘土を有する破砕菷地すべりの機構を 解明する目的で一地すべりの挙動を調べ, 若 干の考察を加光たものである。

* 愛蝯大学工学部海洋工学科

**四国地建

\section{2. 地形, 地質, 地すべり挙動の概要}

調査地は結晶片岩類が分布する三波川带の北緣部に位 置して扣り, 北方 $100 \mathrm{~m}$ に中央構造線が走っている。Fig. 1 亿平面図を，Fig. 2 亿縱断面図 (A-A 断面) を示卞。

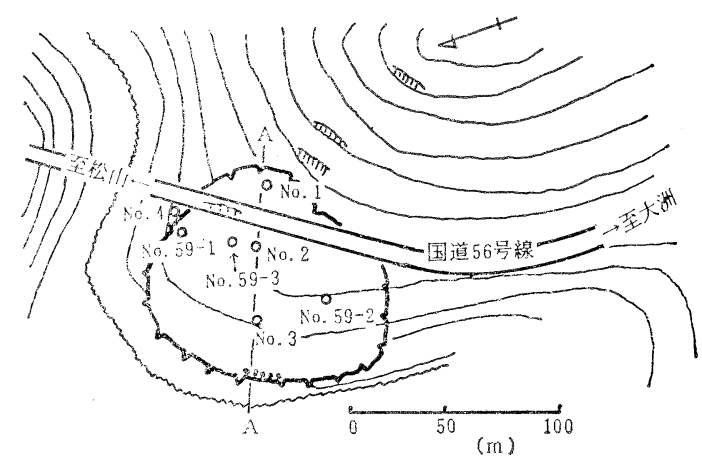

Fig. 1 Plane figure

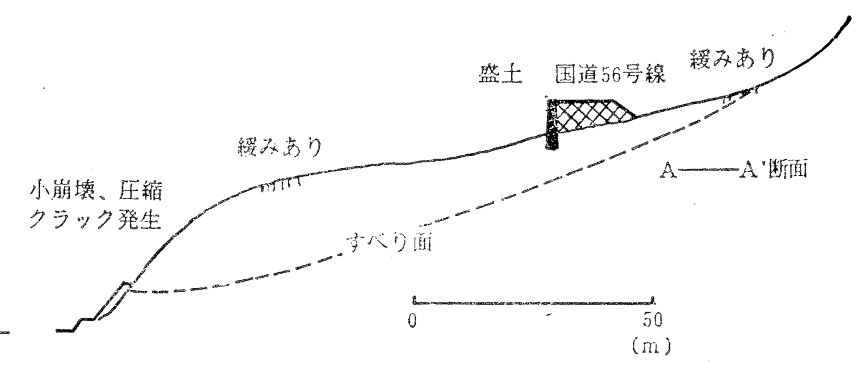

Fig. 2 Vertical section of slope 
平面図にはボーリング孔の位置を併記してある。調査地 の基盤である三波川結晶片岩類は, 斜面の平均傾斜 $\left(25^{\circ}\right.$ $\left.\sim 30^{\circ}\right)$ よりゆるい $10^{\circ} \sim 20^{\circ}$ の層理面をなし流孔盤とな っている。

変状がいつから発生していたか詳しいことは不明であ るが，昭和44年の国道改修後には明らかな変状が認めら れ, 以後, 変状は継続している。Fig. 3 亿孔内傾斜計の 観測結果（No.2，昭和57.4 58.12）の 1 例尜す。す ベり面は厚さ約 $1 \mathrm{~m}$ で粘土化している。地すべり粘土は 他のボーリング孔でも確認されて特り,すべり面上に連 続して存在しているものと思われる。

地下水位の変動の影響をみるため孔内水位観測を行な った。深さ30m の镍測孔 No. 1, 2, 3，59-1，59-2では， すべり面上に水位は存在しなかった。しかし，すべり面 よりわずか深い観測孔 No. 59-3では Fig. 4 に示すよう に，すべり面より上に地下水位が存在し，10 20 $\mathrm{mm}$ の 降雨で40 60 $\mathrm{cm}$ の水位上昇を示している。すべり面よ り上の地下水位は地すべり粘土を不透水層として存在し ているのであろう。地すべり機構の解明や安定解析を行 なら際, 地下水位の把握は重要であるので注意が必要で ある。李た，Fig. 5 は 3 カ月単位で取った平均変位速度

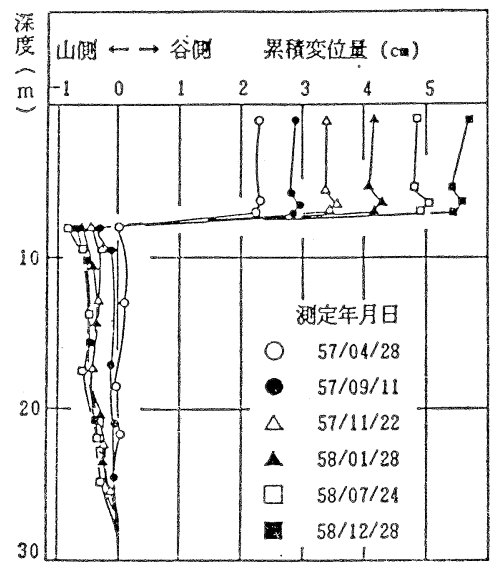

Fig. 3 Observations of bore hall inclinometer

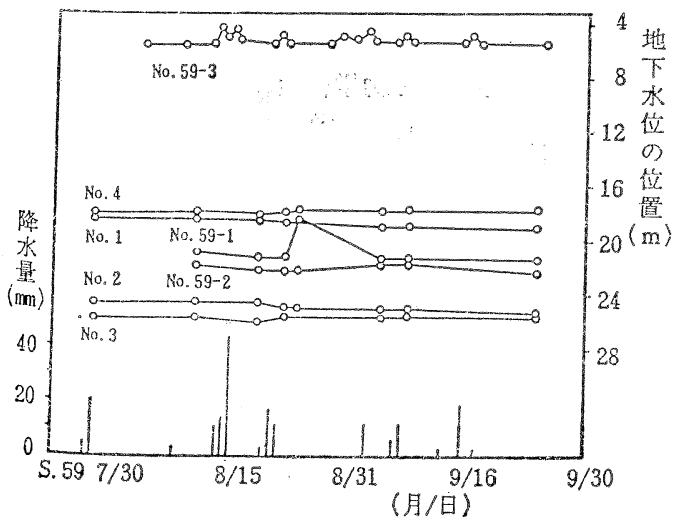

Fig. 4 Observations of ground water levle

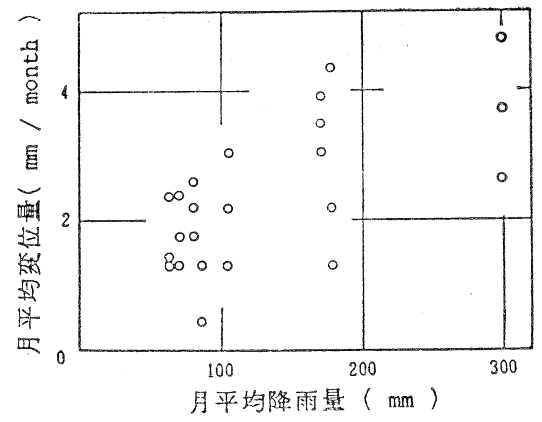

Fig. 5 Relationship between monthly average displacement and monthly average amount of rainfall

と平均月降雨量の関係であるが，かなりな正の相関があ るようである。

以上のことから，この地すべりは粘土層をすべり面と して, 降雨泮う地下水位の変動の影響を大さく受けて いることがわかる。

\section{3. 地すべり粘土の強度, 変形特性}

地すべりの対策工の効果の検討漈しては, 現状の安 全率を 1 と仮定して, 逆算して求めた $c, \phi$ を用いてい る。しかし，前述したような理由で，その方法は必ずし も妥当であるとは思えない。

設計にあたっては多くの手間をか子て得たボーリング 試料は柱状図を描くためだけに使用されている場合が多 く，地すべり粘土等の物性は注とんど調べられていない。

乱して再圧密した試料の压密, せ九断特性は不かく乱 状態でのそれと当然異なる。したがって, 現地で不かく 乱試料をサンプリングして，その試料により物性を調ベ ることが望ましい。しかし，サンプリング時の乱れの問 題やサンプリングの困難さから不かく乱試料での試験は 非常に困難である。

地すべり粘土は長い年月にわたって, せん断, 再王密 の繰り返しで大変形を受けて和り, い和ゆる通常の正規 圧密状態, 過圧密状態の試料の圧密, せ几断特性之は異 なるであろう1)。しかし, 安定解析などに用いる土の有 効応力基準飞よる $c^{\prime} ， \phi^{\prime}$ のらら， $\phi^{\prime}$ は不変と言わ机て いる。一方， c'は応力履歴の影響を受けて変化するのが 一般的である。そこで, 焉ず, せん断, 再圧密の繰り返 しで大変形を受けた粘性土の有効応力基準による $c^{\prime}, \phi^{\prime}$ の変化を調べた。次に，地すべり粘土を試料として用い て, 正規圧密状態, 過圧密状態での圧密, 女九断特性を 压密非排水三軸圧縮試験により調べた。

\section{3-1 大変形を受けた再圧密粘性土の強度定数 $\left.{ }^{2)}, 3\right)$}

(1) 試料, 実験方法

試料には砥部燒きに使う粘性土とシルト質の赤土を用 いた。試料として地すべり粘土を使用すればよいが，一 般的な力学特性を見出すには多量の試料を必要とするの 


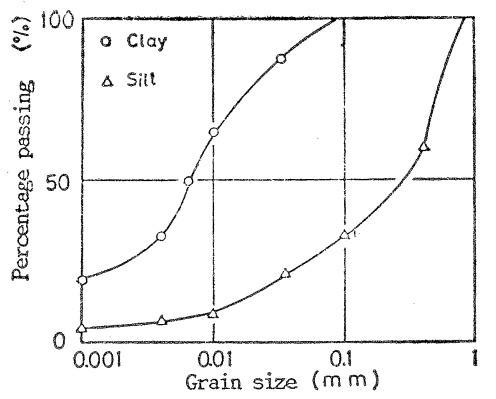

Fig. 6 Grain size distribution curve

でこのような試料を用いた。粘性土の物性は， $L L=49$ $\%, P L=27 \%, G_{s}=2.68$ であり, シル卜質の赤土は $L L$ $=56 \%, P L=33 \%, G_{s}=2.69$ である。Fig. 6亿粒径加積 曲線を示す。

せん断，再圧密の繰り返しで大变形を受けた地すべり 粘土の状態は非常に複雑である。站じりせん断試験機に よってそのような種々の状態を再現して試験を行なって もよいが，今回は完全に乱した試料と乱していない試料 のせん断特性の比較を行なった。

大変形を受㚈た再圧密粘性土の供試体の作成手順は次 のようである。スラリー状から種々の圧密圧力で圧密し た試料を空気を混入させない上う注意して，薄手のゴム スリーブに密封し，手で完全に練り返した。練り返し時 間は試料が充分均一になるよう20３0分とした。このよ らにして作成した試料は，その含水比ではこれ以上に乱 れた状態は有り得ない、乱れの限界の状態に覀る。練り返 乙前後の含水此の変化はみられなかった。この試料を三 軸圧縮試験用供試体火成形した。供試体の寸法は高さ80 $\mathrm{mm}$, 直径 $35 \mathrm{~mm}$ である。

実験方法は压密非排水三軸圧縮試験で, 圧縮速度は4. $4 \times 10^{-2} \mathrm{~mm} / \mathrm{min}$ である。圧密忹等方圧で正規圧密試料で は圧密圧力学 $1.0 ， 2.0 ， 3.0,4.0 \mathrm{kgf} / \mathrm{cm}^{2}$ 之し, 過圧密 試料では先行圧密圧力を $4.0,5.0,6.0 \mathrm{kgf} / \mathrm{cm}^{2}$ で過圧密 比を2，5，10 と変兄て実験を行なった。再圧密時間は すべて24時間とした。実験時にはバックプレッシャー2. $0 \mathrm{kgf} / \mathrm{cm}^{2}$ を作用させ, 間隙水圧係数の $B$ 值が 0.95 以上 の供試体についての及試験を行なった。

（2）実験結果抒よび考察

有効応力基準による見かけの粘着力 $c^{\prime}$ 叔よび見かけ の世九断抵抗角 $\phi^{\prime}$ を求めるために $\left(\sigma_{1}{ }^{\prime}-\sigma_{3}{ }^{\prime}\right)_{f} / 2$ と $\left(\sigma_{1}{ }^{\prime}\right.$ $\left.+\sigma_{3}{ }^{\prime}\right)_{f} / 2$ の関係を Fig. 7, 8 亿示す。Fig. 7 は粘土の,

Fig. 8は赤土の結果である。四中，NC，OC はそれぞれ 乱れを受けていない試料の正規圧密状態，過圧密状態 を，RNC，ROCは完全に練り返した試料の正規圧密状 態, 過圧密状態を意味している。

$\mathrm{NC}, \mathrm{RNC}, \mathrm{ROC}$ とも原点を通る直線上注注乗って 打り，乱れを受けても極端な $\phi^{\prime}$ の变化はみられないと

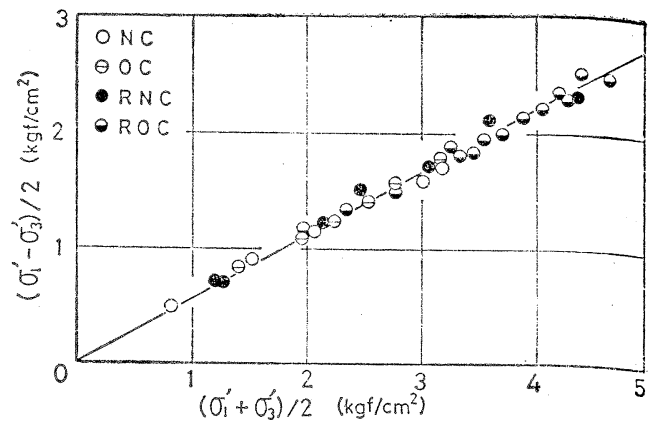

Fig. 7 Failure line terms of effective stress on clay

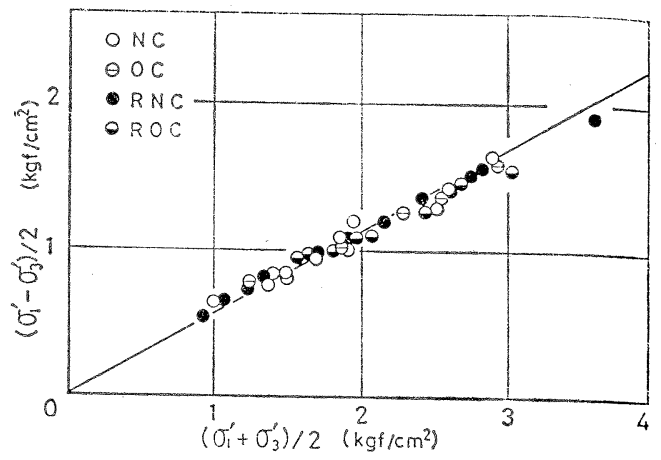

Fig. 8 Failure line terms of effective stress on silty soil

考えてよい。また，今回用いたカオリンが主成分の粘性 土やシルト質土では，OCでの $c^{\prime}$ は小い。

これから，乱したものとそうでないるのとで有效応力

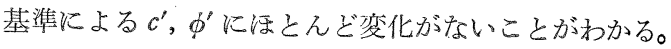
当然のことながら压密特性や応力〜ひずみ〜間隙水圧特 性に違いはある。しかしながら，地すべりの安定解析に

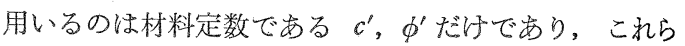
は乱れを受けていても变化しない。したがって, 強度定 数を求める場合, 不かく乱試料の入手が困難であれば再 王密した試料を用いても意味はあるであるう。また, 地 すべり機構の解明や対策工の設計に際して, わずかの手 間で多くの情報が得られるので再圧密した試料に対して でも試験を行なうべきであうう。

\section{3-2 地すべり粘土の力学特性}

前節の実験結果より, 安定解析に用いる $c^{\prime}, \phi^{\prime}$ を求め る場合には再圧密した試料を用いても問題はないである らことが明らかになった。そこで，地すべり粘土の $c^{\prime}$, $\phi^{\prime}$ を求めるため再圧密供試体に対して三軸圧縮試験を行 なった。以下に，その結果を述べる。

\section{（1）試料，実験方法}

試料にはボーリングNo. 3 のすべり面の地すべり粘 土を用いた。試料作成はあたっては $0.44 \mathrm{~mm}$ の篩を通し て碩分掠よび砂分をかなり除いた。粒径加積曲線をFig. 9 亿示す。また，物理的性質を Table 1 亿示す。 
Table 1 Physical properties of specimen

\begin{tabular}{c|c|c}
\hline$G_{s}$ & L. L. & P.L. \\
\hline 2.73 & $35.9 \%$ & $24.2 \%$ \\
\hline
\end{tabular}

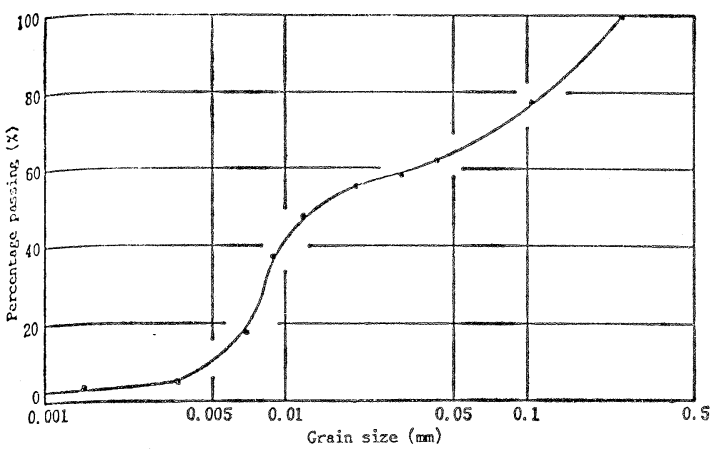

Fig. 9 Grain size distribution curve

試料は液性限界以上の高含水比で完全に練り返し，真 空脱気した後, 王密圧力 $1.0 \mathrm{kgf} / \mathrm{cm}^{2}$ で予压密した。こ のようにして得た圧密試料を成形して, 直径 $35 \mathrm{~mm}$, 高 さ $80 \mathrm{~mm}$ の供試体を作成し，実験に用いた。

実験以圧密非排水条件の三軸試験で行なった。圧密時 間は，全て24時間である。王密時の排水は供試体周面の ペーパードレーンKより行なった。

非排水三軸圧縮試験は正規圧密状態，過圧密状態の供 試体に対して行なった。正規圧密の昜合の圧密圧力は2. $0,3.0,4.0 \mathrm{kgf} / \mathrm{cm}^{2}$ である。過圧密の場合は先行压密生 力を $3.0 \mathrm{kgf} / \mathrm{cm}^{2}$ として，過圧密比を $10 ， 5 ， 2$ ，すなわ ち, せ九断時の圧密圧力を $0.3,0.6,1.5 \mathrm{kgf} / \mathrm{cm}^{2}$ で試験 した。載荷速度は $4.4 \times 10^{-2} \mathrm{~mm} / \mathrm{min}$ である。

三軸圧縮試験時にはバックプレッシャー2.0kgf $/ \mathrm{cm}^{2}$ 作用させ, 間隙水圧係数の $B$ 值が 0.95 以上の供試体 についてのみ試験を行なった。

(2) 実験結果と考察

(1) 压密特性

圧密時間曲線を Fig. 10 に示す。これから, 压密係数 $C_{v}$ は2. $54 \times 10^{-4} \mathrm{~cm}^{2} / \mathrm{sec}$ と求まる。

圧密沈下曲線をFig.11飞示す。これから，圧縮指数

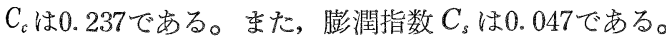
前述したように，地すべり粘土のような大変形を受け て乱れた試料の圧密特性は，乱れを受けていない試料の それとは異なる。したがって，実際の地すべり粘土の圧 密に関する各種の係数は, 今回求めたものより小さくな るであるら 22,3。

\section{(2) せ九断特性}

正規圧密状態での軸差応力〜軸ひずみ〜間隙水圧の関 係を Fig. 12に，過圧密状態での軸差応力〜軸ひずみ〜間 隙水圧の関係を Fig. 13 亿示す。破壊時の間隙水圧係数 $A_{f}$ 之圧密圧力の関係を Fig. 14k示す。

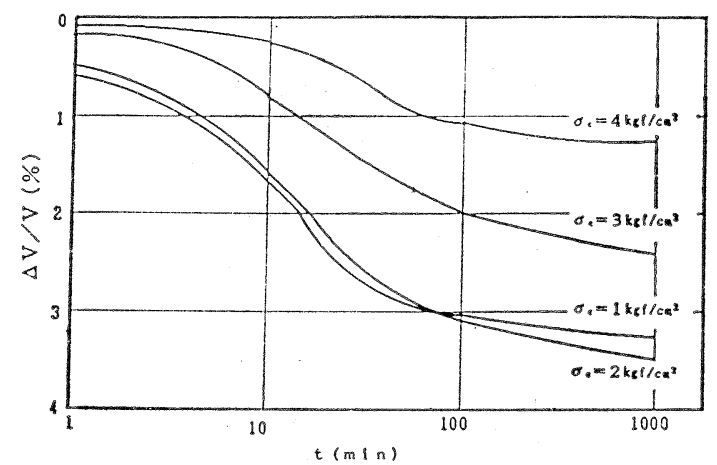

Fig. 10 Settlement time curve

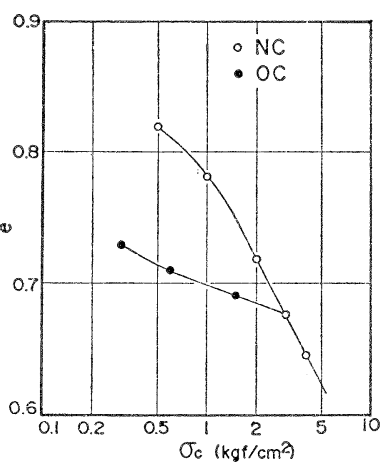

Fig. $11 e \sim \log \sigma_{c}^{\prime}$ curve

軸差応力〜軸ひずみ〜間隙水王の関係をみると，一般 の粘土と同様な挙動を示して和り，今回の地すべり粘土 が特殊なものではないことがわかる。破壞時の間陌水圧 係数も, 従来一般の粘土に対して言われている值の間に あるよらである。

有效応力基準による見か忷の粘着力 $c^{\prime}$, 見かけの内部 摩擦角 $\phi^{\prime}$ を求めるため $\left(\sigma_{1}{ }^{\prime}-\sigma_{3}{ }^{\prime}\right)_{f} / 2$ と $\left(\sigma_{1}{ }^{\prime}+\sigma_{3}{ }^{\prime}\right)_{f} / 2$ の 関係をFig. 15 に示す。同図には有効応力経路を併記し てある。これから $c^{\prime}=0, \phi^{\prime}=30^{\circ}$ と求まる。過压密て

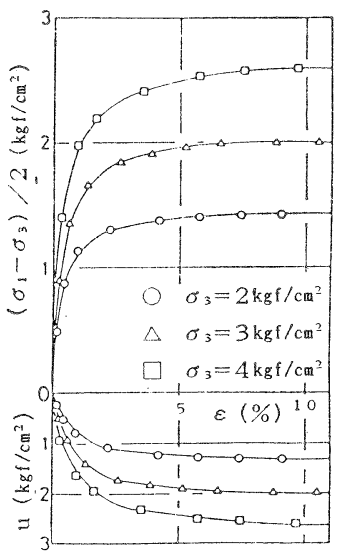

Fig. 12 Relationship between deviator stress, axial strain and volumetric strain on normally consolidated clay 


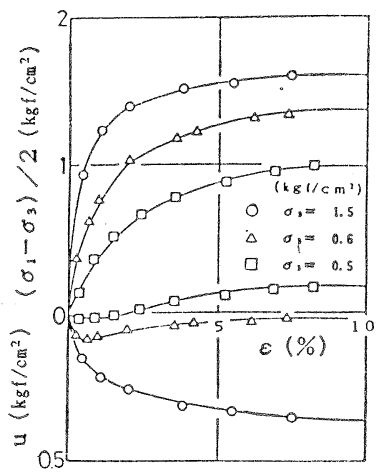

Fig. 13 Relationship between deviator stress, axial strain and volumetric strain on over consolidated clay

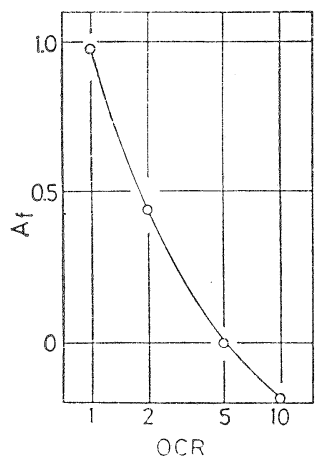

Fig. 14 Relationship between OCR and $A_{f}$

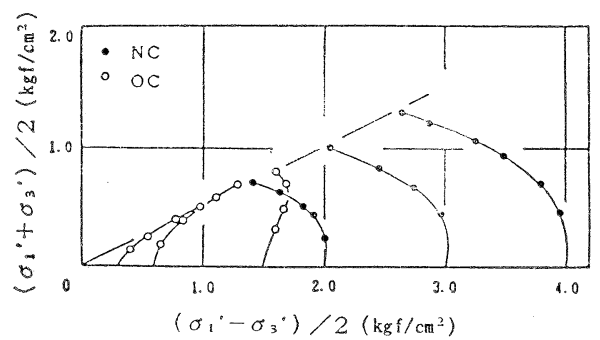

Fig. 15 Effective stress paths for consolidated-undrained tests on clay

はわずかの見かけの粘着力を持つよらである。

不かく乱状態での有効応力経路は, Fig. 15に示したも のとは異なるであるう。しかし，前述したように乱した ものと乱さないるのとでは，有效応力基準に上る見か汗 の粘着力 $c^{\prime}$ ，見かけの内部摩擦角 $\phi^{\prime}$ にあまり違いはな いと考光られるので, 安定解析をこの強度定数を用いて 行なってよいであるう。

\section{4. 安定解析}

（1）解析方法と入力データ

安定解析は非円形のすべり面を仮定するJanbu 法によ り行なっだ。基礎式は次に示すようである。

$$
\begin{aligned}
F_{s} & =\frac{1}{\sum W_{i} \cdot \tan a_{i}} \\
& \times \Sigma \frac{\left(c^{\prime}{ }_{i}-u_{i}+W_{i} / b_{i}\right) \cdot \tan \phi_{i}{ }^{\prime} \cdot F_{s} \cdot\left(1+\tan ^{2} a_{i}\right)}{F_{s}+\tan \phi_{i}{ }^{\prime} \cdot \tan a_{i}}
\end{aligned}
$$

解析手法の詳細は参考文献飞示す5)。

Fig. 16 亿安定解析㴈たっての斜面の断面図を示す。 入力データは次のようである。

$$
\begin{array}{ll}
\text { 粘着力 } & c^{\prime}=0 \mathrm{kgf} / \mathrm{cm}^{2} \\
\text { 内部摩擦角 } & \phi^{\prime}=30^{\circ} \\
\text { 初期間隙比 } & e_{0}=0.56 \\
\text { 乾燥重量 } & \gamma_{d}=1.7 \mathrm{gf} / \mathrm{cm}^{3}
\end{array}
$$

上記の諸定数は斜面内で一様であるとしたが，単位体 積重量は地下水位以下の部分は完全飽和とし，地下水位 より上は $50 \%$ 飽和として求めた。解析は Fig. 16亿示すよ ら飞, 地下水位が存在しない場合, すべり面より上方 1 $2,3,4,5 \mathrm{~m}$ に地下水位が存在する場合に対して行な った。な拈，別に行なった飽和・不飽和浸透解析火より， 総降雨量 $400 \mathrm{~mm}$ 程度で地下水位が $5 \mathrm{~m}$ 程度上昇するこ とが求められている。

(2) 解析結果と考察

Fig. 17亿地下水位の位置と安全率の関係を示す。これ から地下水位が存在しない場合に安全率は1.42であり, 地下水位の上昇飞伴って安全率は低下していることがわ かる。しかし，地下水位が $5 \mathrm{~m}$ になった時点でも安全率

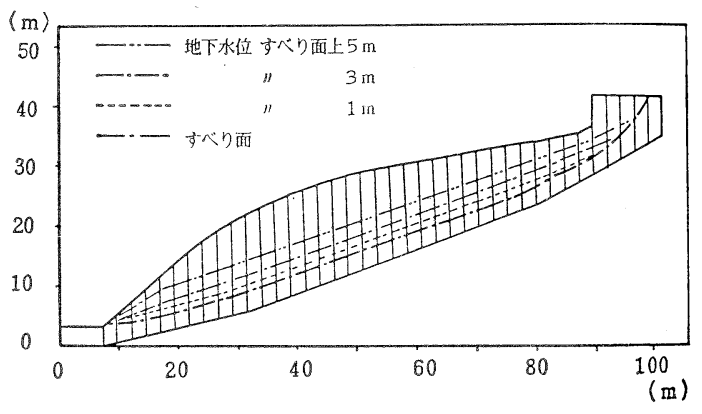

Fig. 16 Vertical section for slope failure analysis

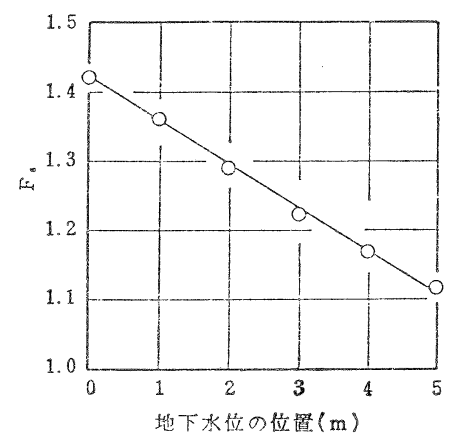

Fig. 17 Relationship between safety factor and ground water level 
は1.12であり、1をきっていない。したがって，現状の ナ゙り面に沿って，斜面全体が一気に崩壊する可能性は 少ないと考えられる。

地すべり粘土の有効応力基準による $c^{\prime}, \phi^{\prime}$ を用いて安 定解析を行なった結果, 現状のすべり面での安全率は 1 ょりかなり大きいことがわかった。これから，本地すべ りの変形挙動は地すべり粘土のクリープにより起こって いることが明らかである。

\section{5. 変形挙動に対する考察}

地すべり粘土が存在する地すべりの変形はクリープ的 に起こっていることが多いと考光られる。それは，もし 地すべり粘土の強度が破壊強度要で発揮されているとし て，現状の安全率が 1 であれぱ一気に大変位が発生する はずであるが，現実にはわずかづつ変位が進行している からである。このような状態では, 地すべり粘土の強度 を破壞強度まで発揮されているとして安定解析を行なっ た場合, 安全率は 1 より大きいはずである。すなわら, 地すべり粘土の強度は破壞強度まで発揮されて扣らず, 破壊強度より小さい応カレベルでクリープ変形が起こっ ている。

上述したように, 地すべり粘土が破壊強度の応力レベ ルまで強度が発揮されずに, それより低い応力レベルで クリープ変形が起こっているとすれば，地すべりの挙動 を解明するために地すべり粘土のクリープ特性を明らか にする必要がある。

そこで，地すべり粘土のクリープ特性を明らかにし， さらに，前節の安定解析結果よりすべり面での応力レベ ルを検討して地すべりの変形挙動に対する検討を行なっ $た_{0}$

\section{5-1＼cjkstart地すべり粘土のクリープ特性}

(1) 試料, 実験方法

試料は前節で用いた地すべり粘土で，その物理的性質 などは前節を参照されたい。供試体の作成方法, 圧密方 法なども同様である。

クリープ試験は三軸非排水状態で行なった。試験の手 順は次のようである。まず, 直径 $35 \mathrm{~mm}$, 高さ $80 \mathrm{~mm}$ の 供試体を段階的に圧密し, 最終的飞圧密圧力 $3.0 \mathrm{kgf} / \mathrm{cm}^{2}$ で王密を行なう。压密が終了した時点で非排水状態にし て, 一定のクリープ荷重を供試体に与党, 軸ひずみ〜間 隙水圧〜経過時間の関係を測定する。クリープ荷重とし ては前節の静的三軸圧縮試験より求めた非排水せん断強 度の $0.5,0.7,0.9,0.95$ 倍になるよら与光た。

間隙水圧の測定は圧力変換器を介して, 静ひずみ計と より行なった。軸荷重はレギュレーターを介して空圧シ リンダールより与充た。各試験は 1 週間程度行なった。

(2) 試験結果招よび考察

次に，実験結果ならびに考察について述べる。Fig. 18
にクリープひずみ速度と経過時間の関係を示す。ここ で， $\tau_{c}$ はクリープせん断荷重であり， $\tau_{s f}$ は静的非排水 三軸圧縮試験に上り求めた非排水強度である。

Fig. 18から $\tau_{c} / \tau_{s f}=0.95$ の場合はクリープ破壞に至り， $\tau_{c} / \tau_{s f}=0.9$ 以下の場合は試験期間内にはクリープ破壊を 起こしていない。クリープ破壊に至らない場合は従来指 摘されているよらに吕，クリープひずる速さと時間の関 係は両対数紙上で直線関係にあり, 各応カレベルで, そ の傾きは添济同じであることがわかる。

地すべり粘土の非排水クリープ試験より，すべり面を 構成している地すべり粘土は明膫なクリープ現象を示す ことが明らかになった。したがって，今まで検討してき た安定解析結果などと併せて, 本地すべりの変形はクリ ープ変形であると断定してよいであるら。

\section{5-2 すべり面の応カレベル}

クリープ速度は応力レベルによって変わるので, 本地 すべり地に扰けるクリープひずみ速度を求める場合, す ベり面に和沪る応力レベルを知る必要がある。しかし， 応力レベルは一様ではなく,すべり面に沿って変化して いる。すべり面の応カレベルを知ることはかなり困難で める。そこで, すべり面での平均的な応力レベルを求め てみる。

Fig. 19飞安全率 $F_{s}$ と内部摩擦角 $\phi_{d}$ の関係を示す。そ れぞれの地下水位の位置に応じて, ある内部摩擦角 $\phi_{d}$ の時に安全率は 1 となっている。ここに, $\phi_{d}$ は排水状態 での内部摩擦角である。

地すべり粘土の排水状態での内部摩擦角 $\phi_{d}$ は, 一般 飞 $\phi^{\prime} \doteqdot \phi_{d}$ であるので約 $30^{\circ}$ であろうが, 安全率が 1 と なる時の内部摩擦角が現に発揮されている内部摩擦角で あり,この内部摩擦角を $\phi_{m}$ で示す。

Fig. 19を参照して安全率が 1 となる時の, この内部摩 擦角 $\phi_{m}$ から次のようにして, すべり面での応カレベル

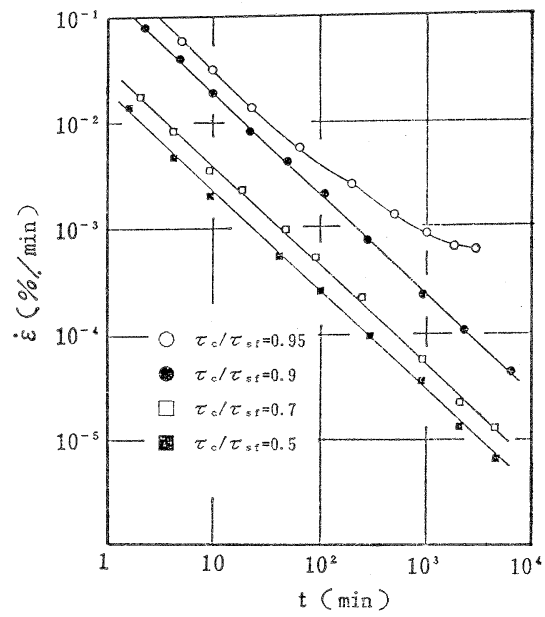

Fig. 18 Log strain rate versus $\log$ time for undrained creep tests on clay 


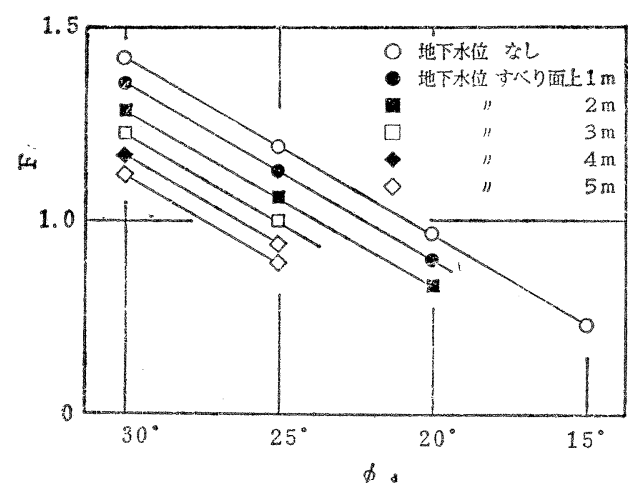

Fig. 19 Changes of safety factor with angle of shearing resistance

を求めることができる。

すべり面で現に発揮されている土のせん断強度は次式 で示される。

$\tau_{m}=c_{m}+\sigma_{c} \tan \phi_{m}$

$c_{m} \doteqdot 0$ ○゙あるので，式(2)から次式のようになる。

$\tau_{m} / \sigma_{c}=\tan \phi_{m}$

これふら, 応力比 $\left(\tau_{m} / \tau_{s f}\right)$ は次式で示される。

$$
\frac{\tau_{m}}{\tau_{s f}}=\frac{\tau_{m} / \sigma_{c}}{\tau_{s f} / \sigma_{c}}=\frac{\tan \phi_{m}}{\tan \phi_{d}}
$$

ここで, サフィクス 度, 粘着力, 内部摩擦角意味し, $\sigma_{c}{ }^{\prime}$ は有効土被り圧 を意味している。

これから，各地下水位の位置での応力比 $\left(\tau_{m} / \tau_{s f}\right)$ は Table 2 のようにな。Table 2 に示す $\tau_{s f}$ は地すべり粘 土の静的せん断強度である。

\section{5-3 クリープ的な観点からの変形举動の考察}

前節で地下水位が変化する場合の斜面の応力レペルが 明らかになった。Fg.18に示すよらに応力レベルにより クリープひずる速度は異なる。

Fig. 18を参照して， $\tau_{c} / \tau_{s f}=0.5$ を基準に取ると $\tau_{c} / \tau_{s f}$ $=0.7$ では約 2 倍近いクリープひずみ速度を示し, $\tau_{c} / \tau_{s f}$ =0.9では約10倍近いクリープひずみ速度を示している。

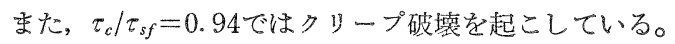

非排水クリープ試験結果とすべり面の応力比の検討結 果をもとに, 地すべりの変形挙動の検討を試みる。とこ ろで，地下氷位の変動の影響を大きく受けているような 地すべりの变形挙動を考えてみると, 降雨浸透に伴う地 下水位変動時には非排水クリープ的举動を示し, 降雨が なく長期間にわたって一定の地下水位を保っている場合 には排水クリープ的な挙動を示すで崩らら。したがっ て，厳密には地すべり粘土の非排水クリープ特性からだ けでなく排水クリープ特性からも検討を試みなければな らないが, 排水クリープ試験を行ならのは非常に困難で あるので, 今回は非排水クリープ試験結果のみから考察
Table 2 Stress ratio correspond to ground water level

\begin{tabular}{|c|c|c|}
\hline \multicolumn{2}{|c|}{ 水面の位置 } & 㐫力比 $\left(\tau_{m} / \sigma_{c}{ }^{\prime}\right) /\left(\tau_{c} / \sigma_{c}{ }^{\prime}\right)$ \\
\hline \multicolumn{2}{|c|}{ 地下水位なし } & 0.658 \\
\hline "f & $1 \mathrm{~m}$ & 0.707 \\
\hline " & $2 \mathrm{~m}$ & 0.763 \\
\hline " & $3 \mathrm{~m}$ & 0.810 \\
\hline$" s$ & $4 \mathrm{~m}$ & 0.852 \\
\hline$n$ & $5 \mathrm{~m}$ & 0.890 \\
\hline
\end{tabular}

を行なら。

前節で検討した応カレベルから判断すると, 地下水位 名存在しない場合 $\left(\tau_{m} / \tau_{s f}=0.558\right)$ を基準に取机ば地 下水位沜 $5 \mathrm{~m}\left(\tau_{m} / \tau_{s f}=0.890\right)$ になると約 5 倍のクリー プひずタ速度となる。Fig. 5で検討したように多雨期, 少雨期で変位速度が $2 \sim 4$ 倍変化していたことと今回の クリープひずみ速度に対する考察から考光ると斜面内で かなり地下水位（間隙水圧）が変化していることが予想 される。

以上のことから, 多雨期, 少雨期に和ける変位速度の 違いは地すべり粘土の再圧密試料の非排水クリープ特性 とすべり面の応カレベルの検討からある程度説明が可能 であることがわかった。しかし，さらに厳密に論じるた めには排水クリープ特性や地下水位の变動に伴ら応力レ ベルの変化を考慮した繰り返しクリープ特性などを明ら かにする必要があるら。

\section{6. あとがき}

地すべり粘土が存在する破挽带地すべりの一調查結果 について報告した。得られた結論は次のよらである。

1）本地すべりは粘土層をすべり面として，降雨に伴 ら地下水位の変動の影響を大きく受けている。

2）大変形を受けた飽和粘性土と乱れを受けていない 飽和粘性土の有效応力基集による強度定数にはほとんど 違いはみられない。

3）地すべり粘土の有効応力基準による強度定数を用 いて安定解析を行なった結果, 現状安全率は 1.4 程度で あり, 変形はクリープにより起こっていることが明らか になった。

4）地すべり粘土のクリープ試験結果とすべの面の応 カレベルの検討から, 多雨期, 少雨期に和以る変位速度 の違いが定性的に明らかになった。

以上, 士の変形, 强度特性を考慮した有効応力的な観 点からの取り組みが必要であることを指摘し，また，そ のアプローチの妥当性を示した。今回は再圧密した試料 の実験結果を用いて安定解析ならびに変形挙動の考察を 行なったが，今後，不かく乱試料の力学特性を解明寸る とともに，地すべりの变形挙動をクリープ特性から定量 的に評価していきたい。 


\section{参考文 歒}

1）小川正二，池田俊雄，趙茂吉，和田正：過圧密状態を考虑 した地すべり斜面の安定解析，第17回土質工学研究発表会 発表講演集，pp.1089 1092，1982。

2）八木則男，与田部龍一，松村真一郎：練り返し時含水比の 買なる再任密土の力学特珄，土木学会椧文報告集，第 330 号, pp. 99〜106、1983.

3）八木則男，矢田部龍一：乱れを受けた飽和粘性土の力学特 任，士木学会論支集，第352昂，pp. 179 186，1984.

4) Janbu, N.: Application of composite slip surfaces for stability analysis, Proc. European Conf. on Stability of Earth Slopes, Vol.3, pp.43 49, 1954.

5）矢田部龍一，榎明潔，八木則男：降雨浸透を考慮した斜面 安定解析法の检討, 地寸べり，Vol.22，No.3，pp.1〜7, 1985.

6) Singh, A. and J.K. Mitchell: General stress-straintime function for soils, Proc. ASCE, Vol.94, No. SM 1, pp. 21 46, 1968.

（原稿受理日 昭和60年12月25日）

\section{「農地地すべり研究会」が発足}

一一昭和61年 5 月 9 日に発会式行われる! -

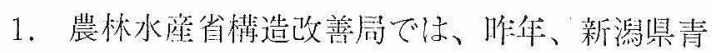
海町や壆野计地附山で発生した地すべり災害が 社会問題となったこと契機に、棈造改善局所 管の地すべり対策について、更に充実強化を园 るため、地卞べり対策全般にわたる諸問題を研 究する農地地与べり㖄究会（通称L A S 研) を 発足させた。

2.この破究会は、農标水産本省、地方農政局及 び都道府県の地すべり担当者で搆成されており、 下部組織として都道府県部会及び各地方農政局 単位で組織する地方部会がある。

3、主な研究活動は次の通りとなっており、この 活動を通じて地すべり対策事業の川滑な推進を 図ることとしている。

1)地すべり技術の向上に関する活動

ア、各地域における地すべりの技術研究

研究発表会、研修会筂の開催

地すべり学会等への積極的参加

亿、地少べり防止技術に関方る情報收集、楅 蒙

2)事菜の川滑な推進に関文当活動

ア、事業推進上の問題点の把层

亿、事業制度の砸究

制度の拡芚・侴没

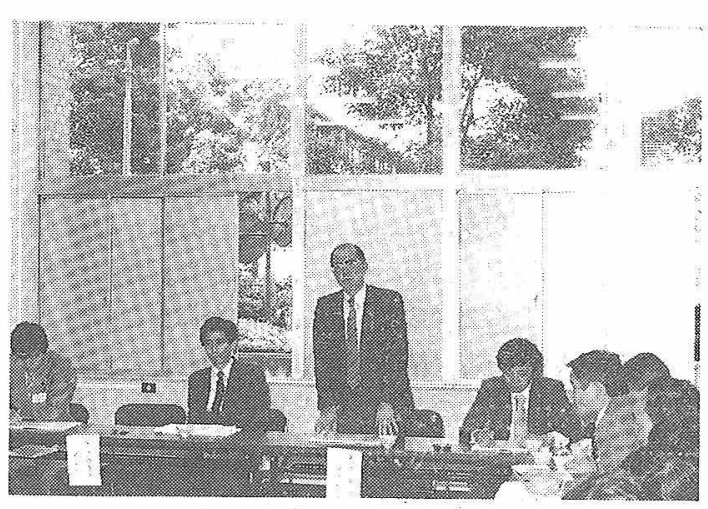

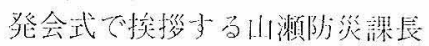

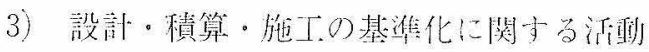
ア、笑態調查の実施之内容の检討

亿、設訃・積算・施工の基售化

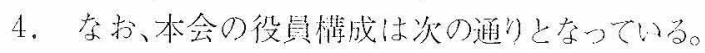

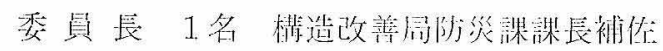

测委真長 2 名”係長

" "資源課係言

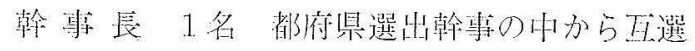
幹事 17 名 地方咷政局及び代表の都道府 県

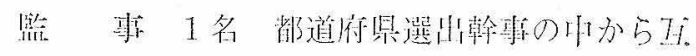
㸃 